\title{
Comparison of Cultivable Acetic Acid Bacterial Microbiota in Organic and Conventional Apple Cider Vinegar
}

\author{
Aleksandra Štornik ${ }^{1}$ Barbara Skok ${ }^{1}$ and Janja Trček $k^{1,2 *}$ \\ ${ }^{1}$ Department of Biology, Faculty of Natural Sciences and Mathematics, University of Maribor, \\ Koroška cesta 160, SI-2000 Maribor, Slovenia \\ ${ }^{2}$ Faculty of Chemistry and Chemical Engineering, University of Maribor, Smetanova ulica 17, \\ SI-2000 Maribor, Slovenia \\ Received: January 23, 2015 \\ Accepted: July 17, 2015
}

\begin{abstract}
Summary
Organic apple cider vinegar is produced from apples that go through very restricted treatment in orchard. During the first stage of the process, the sugars from apples are fermented by yeasts to cider. The produced ethanol is used as a substrate by acetic acid bacteria in a second separated bioprocess. In both, the organic and conventional apple cider vinegars the ethanol oxidation to acetic acid is initiated by native microbiota that survived alcohol fermentation. We compared the cultivable acetic acid bacterial microbiota in the production of organic and conventional apple cider vinegars from a smoothly running oxidation cycle of a submerged industrial process. In this way we isolated and characterized 96 bacteria from organic and 72 bacteria from conventional apple cider vinegar. Using the restriction analysis of the PCR-amplified 16S-23S rRNA gene ITS regions, we identified four different HaeIII and five different HpaII restriction profiles for bacterial isolates from organic apple cider vinegar. Each type of restriction profile was further analyzed by sequence analysis of the 16S-23S rRNA gene ITS regions, resulting in identification of the following species: Acetobacter pasteurianus (71.90\%), Acetobacter ghanensis (12.50\%), Komagataeibacter oboediens (9.35\%) and Komagataeibacter saccharivorans (6.25\%). Using the same analytical approach in conventional apple cider vinegar, we identified only two different HaeIII and two different HpaII restriction profiles of the 16S-23S rRNA gene ITS regions, which belong to the species Acetobacter pasteurianus (66.70\%) and Komagataeibacter oboediens $(33.30 \%)$. Yeasts that are able to resist $30 \mathrm{~g} / \mathrm{L}$ of acetic acid were isolated from the acetic acid production phase and further identified by sequence analysis of the ITS1-5.8S rDNAITS2 region as Candida ethanolica, Pichia membranifaciens and Saccharomycodes ludwigii. This study has shown for the first time that the bacterial microbiota for the industrial production of organic apple cider vinegar is clearly more heterogeneous than the bacterial microbiota for the industrial production of conventional apple cider vinegar. Further chemical analysis should reveal if a difference in microbiota composition influences the quality of different types of apple cider vinegar.
\end{abstract}

Key words: microbiota, organic and conventional apple cider vinegar, Acetobacter, Gluconacetobacter, Komagataeibacter

\section{Introduction}

Apple cider vinegar, alongside wine and alcohol vinegars, is one of the three most common vinegars available on the European market. Given the availability of raw materials, apple cider vinegar is often produced by households for their own needs using a traditional spon- 
taneous process carried out by a native microbiota present on the fruit. Due to market demand, apple cider vinegar is also produced industrially. Alcohol and wine vinegars as well as apple cider vinegar are most often produced in submerged bioreactors, which supply the bacteria with a constant inflow of oxygen and enable an efficient production process (1).

A key factor in the quality of the product, besides the technology of the bioprocess, is the microbiota converting the main substrate, ethanol, into acetic acid, and also producing by-products that influence the chemical composition of the product and, most interestingly from the consumer's point of view, develop the specific aroma of the vinegar (2-4). In recent years some papers have analyzed the bacterial microbiota in the production of different types of vinegars: alcohol, wine, rice, persimmon, strawberry and other types of fruits (5-12). These data suggest that in a vinegar with high percentage of acetic acid ( $>6$ $\%)$ the predominant species are Komagataeibacter europaeus, Komagataeibacter oboediens and/or Komagataeibacter intermedius, whereas in vinegar with low percentage of acetic acid $(<6 \%)$, the predominant species are Acetobacter aceti, Acetobacter pasteurianus and/or Acetobacter pomorum (5-12). Komagataeibacter is a novel, recently described genus of acetic acid bacteria to which the species formerly accommodated to the Gluconacetobacter xylinus group have been classified $(13,14)$.

The difficulties in isolation and identification of acetic acid bacteria have been emphasized many times in recent years $(5,10,15-17)$. Molecular biology methods are at present the best choice for quick and accurate identification of acetic acid bacteria (16). There are different methods among molecular biology approaches for identification of the isolated acetic acid bacteria that have been tested in recent years: plasmid profiling $(18,19)$, random amplified polymorphic DNA-polymerase chain reaction (RAPD-PCR) (5), denaturing gradient gel electrophoresis (DGGE) of the PCR-amplified partial 16S rRNA gene (20), restriction fragment length polymorphism (RFLP) of the PCR-amplified 16S-23S rRNA gene ITS region (21), PCR of specific region on nifH, nifD (22) or adhA (16), enterobacterial repetitive intergenic consensus (ERIC)-PCR (8), rep-PCR (23), DNA-DNA hybridization (24), (GTG) 5 -PCR $(5,23)$, sequence analysis of housekeeping genes (25) and matrix-assisted laser desorption ionization time-of-flight mass spectrometry (MALDI-TOF MS) (26). Some of these methods are very easy to perform and do not need very expensive equipment, such as RFLP of specific PCR products, whereas others, for example DNA-DNA hybridization or MALDI-TOF MS, depend on more experienced laboratory stuff and expensive equipment that not all laboratories interested in this subject can afford. Taking into account these issues, we think that the method based on the analysis of the 16S-23S rRNA gene ITS region is a reasonable choice for identification of acetic acid bacteria, especially among genera Acetobacter and Komagataeibacter (previously Gluconacetobacter), whose 16S rRNA gene sequences are very similar to each other. The method was used quite often in recent years for the identification of acetic acid bacteria from different sources, as an alternative genetic marker for novel species description, and it also turned out to be useful for fishing out novel species of acetic acid bacteria $(16,21,27,28)$. Besides the methods mentioned above, the DGGE analysis of the PCR-amplified partial 16S rRNA gene has been used for direct characterization of vinegar microbiota; it enables microbial identification by culture-independent molecular approach (29-31).

Nowadays consumers are increasingly aware of the importance of eating healthy food. The number of consumers who regularly buy organic food is therefore growing. The vinegar industry in Slovenia is trying to follow these trends and is producing organic apple cider vinegar in limited amounts in accordance with the availability of organic apple cider. Because of the differences in apple tree treatments used in the production of organic and conventional apple cider vinegar, the microbiota brought from the surface of the apples to the cider is expected to be different. The aim of this work is to systematically follow the cultivable bacterial microbiota during a smoothly running oxidation cycle of organic and conventional industrial submerged apple cider vinegar production by restriction and sequence analysis of the PCR-amplified 16S-23S rRNA gene ITS regions.

\section{Materials and Methods}

\section{Sampling of vinegars and isolation of microorganisms}

Non-filtered vinegars were sampled directly from an 8000 -litre broth of industrial submerged bioreactors for production of organic and conventional apple cider vinegars from the beginning to the end of one smoothly running oxidation cycle. The oxidation cycles were sampled during different stages of the oxidation, meaning that at the point of sampling the concentration of acetic acid and volume fraction of ethanol were different. Both bioprocesses with sampling points are presented in Fig. 1. At each of the sampling points the unfiltered vinegar was brought from the bioreactor to the industrial laboratory and immediately spread aseptically onto the reinforced acetic acid and ethanol (RAE) medium (containing in g/L: glucose 40, peptone 10 , yeast extract 10 , citric acid 1.37, $\mathrm{Na}_{2} \mathrm{HPO}_{4} \cdot 2 \mathrm{H}_{2} \mathrm{O} 3.38$ and agar 10 ) containing $1 \%$ (by volume) of acetic acid and $1 \%$ (by volume) of ethanol, and incubated at $30{ }^{\circ} \mathrm{C}$ and high humidity (32). Each sampling point was analyzed in triplicates. The conventional apple cider vinegar was sampled between 28 and 31 May 2013 and the organic apple cider vinegar from 15 to 18 January 2014 at the premises of the Šampionka company, located in the settlement of Volčja Draga in western Slovenia. At each of the sampling points four colonies were selected from each replicate, purified after preculturing three times on the same type of medium and preserved in RAE medium with $20 \%$ of glycerol at $-80{ }^{\circ} \mathrm{C}$.

\section{Acetic acid and ethanol analysis}

The concentration of acetic acid and volume fraction of ethanol were analyzed in each sample of vinegar. The acidity of the samples was determined by titrating the samples with $0.1 \mathrm{M} \mathrm{NaOH}$ in the presence of phenolphthalein. The acetic acid in vinegar represents $98 \%$ of acids (33); the total acidity is therefore also a measure for acetic acid concentration. Ethanol volume fraction was determined ebullioscopically (34). 
a)

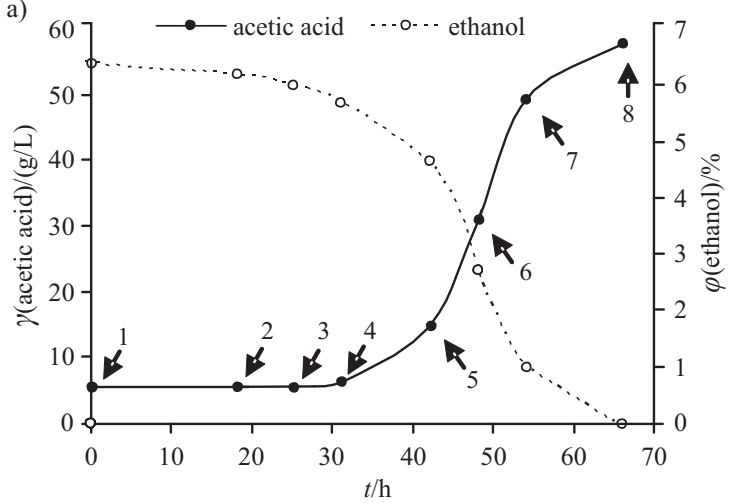

b)

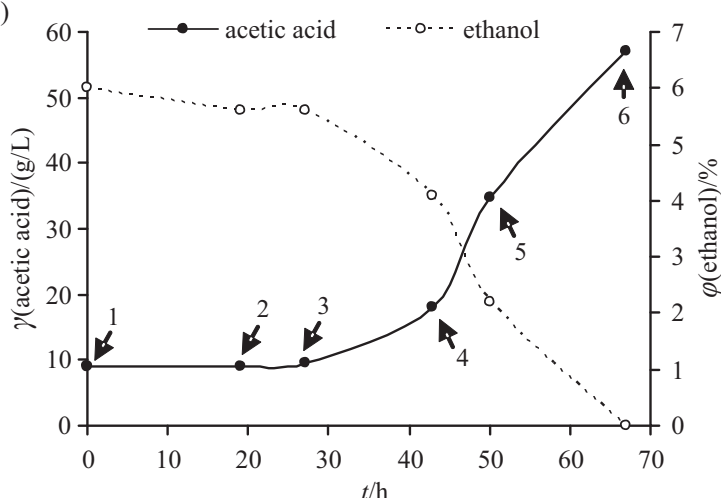

Fig. 1. Concentration of acetic acid and volume fraction of ethanol during the oxidation cycle of: a) industrial organic apple cider vinegar production, and b) the industrial conventional apple cider vinegar production. The numbers correspond to the sampling points of the microbial cultures

\section{Phenotypic characterization of isolates}

Each bacterial isolate was examined microscopically after Gram staining. The presence of cytochrome c oxidase and catalase was determined in bacterial smear after covering the cells with a few drops of $1 \%$ tetramethyl-p-phenylenediamine and $3 \% \mathrm{H}_{2} \mathrm{O}_{2}$, respectively.

The maximal resistance of yeasts to acetic acid was determined by growing the isolates on a RAE medium with $1 \%$ (by volume) of ethanol and appropriate volume fraction of acetic acid (1-4\%).

\section{DNA isolation procedure}

The bacterial isolates were grown in a liquid RAE medium containing $1 \%$ (by volume) of acetic acid and 1 $\%$ (by volume) of ethanol. After reaching the exponential growth phase $\left(A_{600 \mathrm{~nm}}=0.5-1.0\right)$, the biomass was harvested and the DNA was isolated using the commercial kit NucleoSpin Tissue (Macherey-Nagel GmbH\&Co. KG, Düren, Germany).

\section{Identification of bacteria by 16S-23S rRNA gene ITS restriction and sequence analysis}

The PCR amplification of the 16S-23S rRNA gene ITS was performed with primers Spacer_Fw (5'-TGCGG(C/T) TGGATCACCTCCT-3') (position 1522-1540 on 16S rRNA gene, Escherichia coli numbering) and Spacer_Rev (5'-GTGCC(A/T)AGGCATCCACCG-3') (position 38-22 on 23S rRNA gene, E. coli numbering) as described previously (35). The PCR products were digested separately with HaeIII and HpaII restriction enzymes and the restriction profiles obtained were compared to the original database of restriction profiles established with the reference strains published up to 2002 (35) as well as to an extended database established with the recently described reference strains of acetic acid bacteria (kept at the Department of Biology of the Faculty of Natural Sciences and Mathematics at the University of Maribor, Slovenia). The 16S-23S rRNA gene ITS regions that gave different restriction profiles were sequenced at Eurofins Genomics (Ebersberg, Germany).

The length of restriction fragments of the novel restriction profiles was calculated relative to that of DNA marker by linear regression of the semilogarithmic curve (mobility vs. logarithm of DNA fragment length).

The sequences were compared to the homologous sequences of the reference strains through National Center for Biotechnology Information (NCBI), consisting of GenBank/EMBL/DDBJ databases and assigned to the species with the highest nucleotide identity. The sequences were deposited into EMBL/GenBank/DDBJ databases (International Nucleotide Sequence Database Collaboration) under accession numbers given in Table 1.

Table 1. Typical restriction types of the PCR-amplified 16S-23S rDNA ITS regions of bacterial isolates from apple cider vinegars, accession numbers of the corresponding 16S-23S rRNA gene ITS sequences and species identity based on these regions

\begin{tabular}{|c|c|c|c|}
\hline \multicolumn{2}{|c|}{ Restriction types } & \multirow{2}{*}{$\begin{array}{c}\text { Isolate } \\
\text { designation }\end{array}$} & \multirow{2}{*}{$\begin{array}{l}\text { Identification } \\
\text { (accession number) }\end{array}$} \\
\hline HaeIII & HpaII & & \\
\hline$Z_{1}$ & $\mathrm{~W}_{1}$ & BJK_2A & $\begin{array}{l}\text { Acetobacter ghanensis } \\
\text { (LN613137) }\end{array}$ \\
\hline $\mathrm{Z}_{1}$ & $\mathrm{~W}_{2}$ & BJK_2B & $\begin{array}{l}\text { Acetobacter ghanensis } \\
\text { (LN613138) }\end{array}$ \\
\hline $\mathrm{SV}_{1}$ & $\mathrm{TV}_{1}$ & BJK_3A & $\begin{array}{l}\text { Komagataeibacter saccharivorans } \\
\text { (LN613139) }\end{array}$ \\
\hline $\mathrm{P}_{1}$ & $\mathrm{R}_{1}$ & BJK_3B & $\begin{array}{l}\text { Acetobacter pasteurianus } \\
\text { (LN613140) }\end{array}$ \\
\hline $\mathrm{I}_{1}$ & $\mathrm{~J}_{2}$ & BJK_8B & $\begin{array}{l}\text { Komagataeibacter oboediens } \\
\text { (LN613141) }\end{array}$ \\
\hline
\end{tabular}

\section{Identification of yeasts by ITS1-5.8S rDNA-ITS2 sequence analysis}

Morphologically different types of yeast colonies from each type of vinegar were analyzed by sequence analysis of ITS1-5.8S rDNA-ITS2. PCR amplification of this region was performed with primers 18SF1 (5'-AGGTTTCCGTAGGTGAACCT-3') and ITS4 (5'-TCCTCCGCTTATTGATATGC-3') as described previously (36). The PCR products were sequenced at Eurofins Genomics. The sequences were analyzed as described above for bacteria and deposited into EMBL/GenBank/DDBJ databases under accession numbers given in Table 2. 
Table 2. Yeasts isolated from apple cider vinegars and their species identity based on ITS1-5.8S rDNA-ITS2 sequences

\begin{tabular}{lcl}
\hline Source & $\begin{array}{c}\text { Isolate } \\
\text { designation }\end{array}$ & $\begin{array}{l}\text { Identification } \\
\text { (accession number) }\end{array}$ \\
\hline $\begin{array}{l}\text { Organic } \\
\text { apple cider } \\
\text { vinegar }\end{array}$ & BJK_1A & Candida ethanolica (LN613144) \\
& BJK_3C & Pichia membranifaciens (LN613145) \\
& BJK_5C & Saccharomycodes ludwigii (LN613146) \\
\hline BJK_6B & Saccharomycodes ludwigii (LN613147) \\
apple cider & JK_T2K1 & Candida ethanolica (LN613148) \\
vinegar & JK_T4K1 & Candida ethanolica (LN613149) \\
& JK_T4K3 & Candida ethanolica (LN613150) \\
& JK_T5K1 & Saccharomycodes ludwigii (LN613151) \\
& JK_T5K2 & Candida ethanolica (LN613152) \\
& JK_T7K1 & Candida ethanolica (LN613153) \\
\hline
\end{tabular}

\section{Typing of bacteria by RAPD-PCR analysis}

RAPD-PCR was performed essentially as described previously by Trček et al. (5), with minor modifications. PCR was performed in a $20-\mu \mathrm{L}$ reaction mixture containing approx. $10 \mathrm{ng}$ of DNA, $2.5 \mathrm{mM}$ of $\mathrm{MgCl}_{2}, 40 \mathrm{pmol}$ of primer, $0.5 \mathrm{U}$ of Taq DNA polymerase (Thermo Scientific, Waltham, MA, USA), $0.2 \mathrm{mM}$ of dNTP (Thermo Scientific) and $2 \mu \mathrm{L}$ of $10 \times \mathrm{Taq}$ buffer (Thermo Scientific). Based on the number and reproducibility of the amplified bands, two primers were selected: $(\mathrm{GTG})_{5 \times}$ and $80 \%(\mathrm{G}+\mathrm{C})$. The cycling programme started with initial denaturation of DNA at $95{ }^{\circ} \mathrm{C}$ for $3 \mathrm{~min}$ and continued with 30 cycles at $95{ }^{\circ} \mathrm{C}$ for $30 \mathrm{~s}$, at $56^{\circ} \mathrm{C}$ (primer (GTG) 5 ) for $30 \mathrm{~s}$ or $41{ }^{\circ} \mathrm{C}$ (primer $80 \%(\mathrm{G}+\mathrm{C})$ ) for $30 \mathrm{~s}$ and at $72{ }^{\circ} \mathrm{C}$ for $1 \mathrm{~min}$. At the end, a final extension at $72{ }^{\circ} \mathrm{C}$ for $7 \mathrm{~min}$ was performed, followed by cooling at $4{ }^{\circ} \mathrm{C}$. The PCR products were separated in $1.5 \%$ agarose gel in $1 \times$ Tris-acetate running buffer.

\section{Results and Discussion}

\section{Description of the bioprocesses}

The oxidation of ethanol to acetic acid during apple cider vinegar production is initiated by microbiota that originates from the surface of apples. These species have to survive the fermentation of sugars to ethanol and the conditions in the submerged bioreactor for the vinegar production. Since the industry strives to conduct the bioprocess economically, part of the previous cycle is typically used as a starter for the next cycle of the bioprocess after the process is successfully initiated. The acidity of the oxidation cycle at time zero is therefore above zero, as shown in Fig. 1. The duration of both cycles, for the production of organic and of conventional apple cider vinegar, was approx. the same at 66 and $67 \mathrm{~h}$, respectively. The acidity reached at the end of each cycle was the same, i.e. $57 \mathrm{~g} / \mathrm{L}$. This value depends mostly on the sugar content in apples. According to these technological parameters, which are also typically followed by industry technologists to evaluate the performance of the vinegar-producing process, both bioprocesses performed in a similar way.

Although the same vinegar samples were inoculated onto more RAE agar media, with the aim of observing the
$\mathrm{CFU} / \mathrm{mL}$, the variations were extremely large, up to $100-$ -fold, suggesting that the number of microorganisms as determined by the cultivation approach is not suitable for following the number of microorganisms from submerged bioreactors. This observation has already been described for alcohol and wine vinegars (16).

Both processes, for organic and for conventional apple cider vinegar production, were sampled at the beginning of the cycle when the volume fraction of ethanol was maximal, $6.3 \%$ in organic apple cider vinegar and $6 \%$ in conventional apple cider vinegar, then several more times during each oxidation cycle, and at the end of the cycle, when the process achieved the maximal concentration of acetic acid (Fig. 1). Because the samples were taken manually and also because the processes started at different times of the day, the samples could not be taken during the process at exactly the same points. However, both processes had the same pattern from the very initial stage of oxidation, i.e. the lag phase, which lasted approx. $30 \mathrm{~h}$ during both processes, and later during a typical exponential phase, when the bacteria oxidized the ethanol with the highest efficiency (Fig. 1).

\section{Identification of isolates from vinegar}

Among 96 bacterial isolates from organic apple cider vinegar, four different $\mathrm{Hae} \mathrm{III}$ and five different $\mathrm{HpaII}$ restriction profiles of the PCR-amplified 16S-23S rRNA gene ITS regions were identified. The dominant combination of HaeIII and HpaII restriction profiles was $\mathrm{P}_{1} \mathrm{R}_{1}$, which is typical for the species Acetobacter pasteurianus. The species identity was confirmed by sequence analysis of the PCR amplified 16S-23S rRNA gene ITS regions of a randomly selected isolate (Table 1). A. pasteurianus represented $71.9 \%$ of all isolates from organic cider vinegar and it persisted to the end of the bioprocess (Table 3). Although in minority, strains were also isolated with a com-

Table 3. List of species and the number of isolates (in parentheses) from organic and conventional apple cider vinegars isolated at different sampling points (see Fig. 1)

\begin{tabular}{|c|c|c|}
\hline 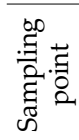 & $\begin{array}{l}\text { Organic apple } \\
\text { cider vinegar }\end{array}$ & $\begin{array}{l}\text { Conventional apple cider } \\
\text { vinegar }\end{array}$ \\
\hline \multirow[t]{2}{*}{1} & Acetobacter pasteurianus (12) & Komagataeibacter oboediens (2) \\
\hline & & Acetobacter pasteurianus (10) \\
\hline 2 & Acetobacter ghanensis (12) & Acetobacter pasteurianus (12) \\
\hline \multirow[t]{2}{*}{3} & $\begin{array}{l}\text { Komagataeibacter } \\
\text { saccharivorans (6) }\end{array}$ & Acetobacter pasteurianus (12) \\
\hline & Acetobacter pasteurianus (6) & \\
\hline 4 & Acetobacter pasteurianus (12) & Komagataeibacter oboediens (12) \\
\hline 5 & Acetobacter pasteurianus (12) & Acetobacter pasteurianus (12) \\
\hline \multirow[t]{2}{*}{6} & Acetobacter pasteurianus (12) & Komagataeibacter oboediens (10) \\
\hline & & Acetobacter pasteurianus (2) \\
\hline 7 & Acetobacter pasteurianus (12) & n.d. \\
\hline \multirow[t]{2}{*}{8} & Komagataeibacter oboediens (9) & n.d. \\
\hline & Acetobacter pasteurianus (3) & \\
\hline
\end{tabular}

n.d.=not determined 
bination of HaeIII and HpaII restriction profiles $\mathrm{I}_{1} \mathrm{~J}_{2}$ from organic apple cider vinegar. The species identity of the isolates with these restriction profiles was also confirmed by sequence analysis to be Komagataeibacter oboediens, previously classified as Gluconacetobacter oboedies (Table 1). K. oboediens represented $9.35 \%$ of all isolates from organic cider vinegar (Table 3 ). In addition, we isolated strains with novel HaeIII and HpaII restriction profiles: $\mathrm{Z}_{1}(480$ and $250 \mathrm{bp}), \mathrm{W}_{1}(600$ and $100 \mathrm{bp}), \mathrm{W}_{2}$ (720 bp), SV $\mathrm{SV}_{1}(320$, 240 and $150 \mathrm{bp}$ ) and $\mathrm{TV}_{1}(490$ and $100 \mathrm{bp}$ ) (Table 1). Since we could not allocate them to any restriction profiles available in the database published in 2002 (35), we sequenced the PCR products. Comparison with the sequences in NCBI database identified the isolates with the restriction profile $\mathrm{SV}_{1} \mathrm{TV}_{1}$ as Komagataeibacter saccharivorans (Table 1). K. saccharivorans represented $6.25 \%$ of all isolates from organic cider vinegar but it was detected only at the beginning of oxidation cycle (Table 3, Fig. 1). For the isolates with restriction profiles $Z_{1} W_{1}$ and $Z_{1} W_{2}$ we further sequenced partial $16 S$ rRNA gene and identified them as Acetobacter ghanensis. For this species the 16S-23S rRNA gene ITS sequence has not so far been known, which explains why we did not detect a high pairwise similarity to any sequences deposited in the NCBI database (Table 1). K. ghanensis represented $12.5 \%$ of all isolates from organic cider vinegar and was also detected only at the beginning of oxidation cycle (Table 3, Fig. 1). In contrast to K. oboediens and K. saccharivorans, which had already previously been isolated from vinegar, the species $A$. ghanensis has not yet been isolated from vinegar, but has been from cocoa beans in Ghana, tomato and peach in Thailand and palm wine in Burkina Faso (28, $37,38)$. This study thus shows that the species A. ghanensis is not restricted to a highly specific ecological niche but that it also colonizes other substrates in nature.

In contrast to organic apple cider vinegar, from conventional apple cider vinegar we isolated only the strains with two different combinations of HaeIII and HpaII restriction profiles. Both combinations $\mathrm{P}_{1} \mathrm{R}_{1}$ and $\mathrm{I}_{1} \mathrm{~J}_{2}$ were previously identified among strains of $A$. pasteurianus and K. oboediens, respectively (35). A. pasteurianus and K. oboediens represented 66.7 and $33.3 \%$ of all isolates from conventional apple cider vinegar, respectively (Table 3). Both species persisted to the end of ethanol oxidation cycle (Table 3).

The species $A$. pasteurianus has often been isolated in recent years from different fruits and vinegars and therefore its presence in both types of apple cider vinegar is not unexpected $(8,10-12,39)$. In both types of vinegar $A$. pasteurianus was the dominant species, persisting to the end of the bioprocess, when the concentration of acetic acid reached almost $60 \mathrm{~g} / \mathrm{L}$ (Fig. 1, Table 3). The species $K$. oboediens is also a common bacterium used for the production of different types of vinegar, and moreover, is a typical species for the production of vinegar with high acetic acid percentage $(7,40)$. All isolates within one type of vinegar identified as $A$. pasteurianus were genotypically identical to one another as detected by RAPD-PCR but different between the two processes. The same findings were observed for the isolates identified as K. oboediens. According to this data, all isolates of the same species in each type of vinegar are genotypically homogeneous, which is likely to be the result of a strong selection pressure that is forcing the best adapted strain.

Very interestingly, we isolated yeasts from both types of vinegar, four isolates from organic apple cider vinegar and six from conventional apple cider vinegar (Table 2): the species Candida ethanolica from the first sampling point with $6.3 \%$ (by volume) of ethanol and $5.3 \mathrm{~g} / \mathrm{L}$ of acetic acid, the species Pichia membranifaciens from the vinegar broth with $5.9 \%$ (by volume) of ethanol and 5.5 $\mathrm{g} / \mathrm{L}$ of acetic acid, and species Saccharomycodes ludwigii from the broth containing $2.7 \%$ (by volume) of ethanol and $30.6 \mathrm{~g} / \mathrm{L}$ of acetic acid. Similarly, we isolated yeasts from the conventional apple cider vinegar, but only the species C. ethanolica and S. ludwigii. All isolated yeasts were resistant against $30 \mathrm{~g} / \mathrm{L}$ of acetic acid and it was not lost by any of the strains after preservation for half a year at $-80^{\circ} \mathrm{C}$. These yeasts probably originate from and have survived through ethanol fermentation to vinegar broth. The presence of so-called non-Saccharomyces yeasts is typical for fermentations yielding low final alcohol content: for example, Hanseniaspora uvarum and Pichia guilliermondii were detected during the fermentation of freshly crushed pineapple juice in Australia and Thailand that yielded 1-4 \% (by volume) of ethanol, and Candida quercitrusa and Issatchenkia terricola were found during gabiroba (Campomanesia spp.) pulp fermentation, which yielded 2.6-3.8 \% (by volume) of ethanol $(41,42)$. The high acetic acid resistance of yeasts isolated and identified in this work is comparable to those of extremely acetic acid-resistant yeast, Zygosaccharomyces bailii (43), and has not been reported before.

\section{Conclusions}

The microbiota represents one of the key components of the vinegar-producing bioprocess starting from different sugar-containing materials. In Slovenia, apple cider vinegar is a traditional product produced in households but also at the industrial level. The industry aims to monitor and control the bioprocess and it is therefore important to know the composition of the microbiota responsible for a well-performing process. In this work we compared for the first time the composition of organic and conventional apple cider vinegars. In both types of vinegar the species Acetobacter pasteurianus was dominant and, in addition, the species Komagataeibacter oboediens was detected. In organic apple cider vinegar the species A. ghanensis and K. saccharivorans were also detected. Yeasts were isolated from both types of apple cider vinegar. Very interestingly, these yeasts resisted up to $30 \mathrm{~g} / \mathrm{L}$ of acetic acid. This study has demonstrated that the microbiota of the organic apple cider vinegar is more heterogeneous than that of conventional apple cider vinegar, which may influence the chemical composition and sensorial quality of vinegars.

\section{Acknowledgements}

This research was funded by the Slovenian Research Agency through programs IP-0552 and P2-0006. Financial support from the Ministry of Education, Science and Sport 
and the European Social Fund under the scheme Practical Knowledge through Creative Pathways is gratefully acknowledged. Mateja Leban from Šampionka company is acknowledged for sampling of vinegars.

\section{References}

1. Ebner H. Vinegar. In: Reed, G, editor. Prescott \& Dunn's industrial microbiology. Avi Publishing, Westport; 1982. pp. 802-34.

2. Tesfaye W, Morales ML, García-Parrilla MC, Troncoso AM. Wine vinegar: technology, authenticity and quality evaluation. Trends Food Sci Tech. 2002;13:12-21. http://dx.doi.org/10.1016/S0924-2244(02)00023-7

3. Giudici P, Gullo M, Solieri L, Falcone PM. Technological and microbiological aspects of traditional balsamic vinegar and their influence on quality and sensorial properties. In: Taylor S, editor. Advances in food and nutrition research, vol. 58 . Burlington, MA, USA: Academic Press; 2009. pp. 137-82. http://dx.doi.org/10.1016/S1043-4526(09)58004-7

4. Ubeda C, Hidalgo C, Torija MJ, Mas A, Troncoso AM, Morales ML. Evaluation of antioxidant activity and total phenols index in persimmon vinegars produced by different processes. LWT - Food Sci Technol. 2011;44:1591-6. http://dx.doi.org/10.1016/j.lwt.2011.03.001

5. Trček J, Ramuš J, Raspor P. Phenotypic characterization and RAPD-PCR profiling of Acetobacter sp. isolated from spirit vinegar production. Food Technol Biotechnol. 1997;35:63-7.

6. Sokollek SJ, Hertel C, Hammes WP. Description of Acetobacter oboediens sp. nov. and Acetobacter pomorum sp. nov., two new species isolated from industrial vinegar fermentations. Int J Syst Bacteriol. 1998;48:935-40. http://dx.doi.org/10.1099/00207713-48-3-935

7. Trček J, Raspor P, Teuber M. Molecular identification of Acetobacter isolates from submerged vinegar production, sequence analysis of plasmid pJK2-1 and application in the development of a cloning vector. Appl Microbiol Biotechnol. 2000;53:289-95. http://dx.doi.org/10.1007/s002530050023

8. Nanda K, Taniguchi M, Ujike S, Ishihara N, Mori H, Ono H, Murooka Y. Characterization of acetic acid bacteria in traditional acetic acid fermentation of rice vinegar (komesu) and unpolished rice vinegar (kurosu) produced in Japan. Appl Environ Microbiol. 2001;67:986-90.

http://dx.doi.org/10.1128/AEM.67.2.986-990.2001

9. González Á, Hierro N, Poblet M, Rozès N, Mas A, Guillamón JM. Application of molecular methods for differentiation of acetic acid bacteria in a red wine fermentation. J Appl Microbiol. 2004;96:853-60. http://dx.doi.org/10.1111/j.1365-2672.2004.02220.x

10. Gullo M, Caggia C, De Vero L, Giudici P. Characterization of acetic acid bacteria in 'traditional balsamic vinegar'. Int J Food Microbiol. 2006;106:209-12.

http://dx.doi.org/10.1016/j.ijfoodmicro.2005.06.024

11. Wu JJ, Gullo M, Chen FS, Giudici P. Diversity of Acetobacter pasteurianus strains isolated from solid-state fermentation of cereal vinegars. Curr Microbiol. 2010;60:280-6. http://dx.doi.org/10.1007/s00284-009-9538-0

12. Hidalgo C, Mateo E, Mas A, Torija MJ. Identification of yeast and acetic acid bacteria isolated from the fermentation and acetification of persimmon (Diospyros kaki). Food Microbiol. 2012;30:98-104. http://dx.doi.org/10.1016/j.fm.2011.12.017

13. Yamada Y, Yukphan P, Vu HTL, Muramatsu Y, Ochaikul D, Nakagawa Y. Subdivision of the genus Gluconacetobacter Yamada, Hoshino and Ishikawa 1998: the proposal of Komagatabacter gen. nov., for strains accommodated to the Glu- conacetobacter xylinus group in the $\alpha$-Proteobacteria. Ann Microbiol. 2012;62:849-59. http://dx.doi.org/10.1007/s13213-011-0288-4

14. Yamada Y, Yukphan P, Vu HTL, Muramatsu Y, Ochaikul D, Tanasupawat S, Nakagawa Y. Description of Komagataeibacter gen. nov., with proposals of new combinations (Acetobacteraceae). J Gen Appl Microbiol. 2012;58:397-404. http://dx.doi.org/10.2323/jgam.58.397

15. Bartowsky EJ, Xia D, Gibson RL, Fleet GH, Henschke PA. Spoilage of bottled red wine by acetic acid bacteria. Lett Appl Microbiol. 2003;36:307-14.

http://dx.doi.org/10.1046/j.1472-765X.2003.01314.x

16. Trcek J. Quick identification of acetic acid bacteria based on nucleotide sequences of the 16S-23S rDNA internal transcribed spacer region and of the PQQ-dependent alcohol dehydrogenase gene. Syst Appl Microbiol. 2005;28:735-45. http://dx.doi.org/10.1016/j.syapm.2005.05.001

17. Torija MJ, Mateo E, Guillamón JM, Mas A. Identification and quantification of acetic acid bacteria in wine and vinegar by TaqMan-MGB probes. Food Microbiol. 2010;27:257-65. http://dx.doi.org/10.1016/j.fm.2009.10.001

18. Teuber M, Sievers M, Andresen A. Characterization of the microflora of high acid submerged vinegar fermenters by distinct plasmid profiles. Biotechol Lett. 1987;9:265-8. http://dx.doi.org/10.1007/BF01027161

19. Trček J. Plasmid analysis of high acetic acid-resistant bacterial strains by two-dimensional agarose gel electrophoresis and insights into the phenotype of plasmid pJK2-1. Ann Microbiol. 2015;65:1287-92. http://dx.doi.org/10.1007/s13213-014-0966-0

20. De Vero L, Giudici P. Genus-specific profile of acetic acid bacteria by $16 \mathrm{~S}$ rDNA PCR-DGGE. Int J Food Microbiol. 2008;125:96-101.

http://dx.doi.org/10.1016/j.ijfoodmicro.2007.02.029

21. Trček J, Barja F. Updates on quick identification of acetic acid bacteria with a focus on the 16S-23S rRNA gene internal transcribed spacer and the analysis of cell proteins by MALDI-TOF mass spectrometry. Int J Food Microbiol. 2015;196: 137-44. http://dx.doi.org/10.1016/j.ijfoodmicro.2014.12.003

22. Loganathan $P$, Nair S. Swaminathania salitolerans gen. nov., sp. nov., a salt-tolerant, nitrogen-fixing and phosphate-solubilizing bacterium from wild rice (Porteresia coarctata Tateoka). Int J Syst Evol Microbiol. 2004;54:1185-90. http://dx.doi.org/10.1099/ijs.0.02817-0

23. De Vuyst L, Camu N, De Winter T, Vandemeulebroecke K, Van de Perre V, Vancanneyt $M$, et al. Validation of the (GTG) $)_{5}$-rep-PCR fingerprinting technique for rapid classification and identification of acetic acid bacteria, with a focus on isolates from Ghanaian fermented cocoa beans. Int J Food Microbiol. 2008;125:79-90.

http://dx.doi.org/doi:10.1016/j.ijfoodmicro.2007.02.030

24. Cleenwerck I, De Vos P. Polyphasic taxonomy of acetic acid bacteria: an overview of the currently applied methodology. Int J Food Microbiol. 2008;125:2-14. http://dx.doi.org/10.1016/j.ijfoodmicro.2007.04.017

25. Cleenwerck I, De Vos P, De Vuyst L. Phylogeny and differentiation of species of the genus Gluconacetobacter and related taxa based on multilocus sequence analyses of housekeeping genes and reclassification of Acetobacter xylinus subsp. sucrofermentas as Gluconacetobacter (Toyosaki et al. 1996) sp. nov., comb. nov. Int J Syst Evol Microbiol. 2010;60:2277-2283. http://dx.doi.org/10.1099/ijs.0.018465-0

26. Andrés-Barrao C, Benagli C, Chappuis M, Ortega Pérez R, Tonolla M, Barja F. Rapid identification of acetic acid bacteria using MALDI-TOF mass spectrometry fingerprinting. Syst Appl Microbiol. 2013;36:75-81.

http://dx.doi.org/10.1016/j.syapm.2012.09.002 
27. González Á, Mas A. Differentiation of acetic acid bacteria based on sequences of 16S-23S rRNA gene internal transcribed spacer sequences. Int J Food Microbiol. 2011;147: 217-22. http://dx.doi.org/10.1016/j.ijfoodmicro.2011.04.005

28. Tanasupawat S, Kommanee J, Malimas T, Yukphan P, Nakagawa Y, Yamada Y. Identification of Acetobacter, Gluconobacter, and Asaia strains isolated in Thailand based on 16S$23 S$ rRNA gene internal transcribed spacer restriction and $16 \mathrm{~S}$ rRNA gene sequence analyses. Microbes Environ. 2009; 24:135-43. http://doi.org/10.1264/jsme2.ME08564

29. De Vero L, Gala E, Gullo M, Solieri L, Landi S, Giudici P. Application of denaturing gradient gel electrophoresis (DGGE) analysis to evaluate acetic acid bacteria in traditional balsamic vinegar. Food Microbiol. 2006;23:809-13. http://dx.doi.org/10.1016/j.fm.2006.01.006

30. Yetiman AE, Kesmen Z. Identification of acetic acid bacteria in traditionally produced vinegar and mother of vinegar by using different molecular techniques. Int J Food Microbiol. 2015;204:9-16. http://dx.doi.org/10.1016/j.ijfoodmicro.2015.03.013

31. Nie Z, Zheng Y, Du H, Xie S, Wang M. Dynamics and diversity of microbial community succession in traditional fermentation of Shanxi aged vinegar. Food Microbiol. 2015;47: 62-8. http://dx.doi.org/10.1016/j.fm.2014.11.006

32. Sokollek SJ, Hertel C, Hammes WP. Cultivation and preservation of vinegar bacteria. J Biotechnol. 1998;60:195-206. http://dx.doi.org/10.1016/S0168-1656(98)00014-5

33. Bertolini L, Castagnetti GB, Gambini G. HPLC determination of organic acids in vinegar. Ind Bevande. 1994;23:324-6 (in Italian).

34. AOAC Official Method. Vinegars. AOAC, vol. 2, 15th ed., Arlington; 1990. pp. 1007-8.

35. Trček J, Teuber M. Genetic and restriction analysis of the 16S-23S rDNA internal transcribed spacer regions of the acetic acid bacteria. FEMS Microbiol Lett. 2002;208:69-75. http://dx.doi.org/10.1111/j.1574-6968.2002.tb11062.x

36. Gutzmer R, Mommert S, Küttler U, Werfel T, Kapp A. Rapid identification and differentiation of fungal DNA in dermato- logical specimens by LightCycler PCR. J Med Microbiol. 2004;53:1207-14.

http://dx.doi.org/10.1099/jmm.0.45779-0

37. Cleenwerck I, Camu N, Engelbeen K, De Winter T, Vandemeulebroecke K, De Vos P, De Vuyst L. Acetobacter ghanensis sp. nov., a novel acetic acid bacterium isolated from traditional heap fermentations of Ghanaian cocoa beans. Int J Syst Evol Microbiol. 2007;57:1647-52. http://dx.doi.org/10.1099/ijs.0.64840-0

38. Ouoba LII, Kando C, Parkouda C, Sawadogo-Lingani H, Diawara B, Sutherland JP. The microbiology of Bandji, palm wine of Borassus akeassii from Burkina Faso: identification and genotypic diversity of yeasts, lactic acid and acetic acid bacteria. J Appl Microbiol. 2012;113:1428-41. http://dx.doi.org/10.1111/jam.12014

39. Perumpuli PABN, Watanabe T, Toyama H. Identification and characterization of thermotolerant acetic acid bacteria strains isolated from coconut water vinegar in Sri Lanka. Biosci Biotechnol Biochem. 2014;78:533-41.

http://dx.doi.org/10.1080/09168451.2014.882758

40. Trcek J, Toyama H, Czuba J, Misiewicz A, Matsushita K. Correlation between acetic acid resistance and characteristics of PQQ-dependent ADH in acetic acid bacteria. Appl Microbiol Biotechnol. 2006;70:366-73. http://dx.doi.org/10.1007/s00253-005-0073-z

41. Chanprasartsuk O, Prakitchaiwattanaa C, Sanguandeekul R, Fleet GH. Autochthonous yeasts associated with mature pineapple fruits, freshly crushed juice and their ferments; and the chemical changes during natural fermentations. Bioresour Technol. 2010;101:7500-9. http://dx.doi.org/10.1016/j.biortech.2010.04.047

42. Duarte WF, Dias DR, de Melo Pereira GV, Gervásio IM, Schwan RF. Indigenous and inoculated yeast fermentation of gabiroba (Campomanesia pubescens) pulp for fruit wine production. J Ind Microbiol Biotechnol. 2009;36:557-69. http://dx.doi.org/10.1007/s10295-009-0526-y

43. Stratford M, Steels H, Nebe-von-Caron G, Novodvorska M, Hayer K, Archer DB. Extreme resistance to weak-acid preservatives in the spoilage yeast Zygosaccharomyces bailii. Int J Food Microbiol. 2013;166:126-34. http://dx.doi.org/10.1016/j.ijfoodmicro.2013.06.025 